\title{
CMAJ 2011 election survey: transparency
}

$\mathrm{H}$ ealth Canada has long been criticized for the systemic secrecy in which it shrouds critical health data and decisionmaking processes, and recent forays into "open government" have done little to unlock that black box.

While the United States and United Kingdom, among other countries, have introduced sweeping measures to improve public access to health data and regulatory processes, health experts argue Canada has "harmonized down," implementing toothless measures to address concerns about transparency in health regulation in some areas, and stalling action indefinitely in others (www.cmaj.ca/cgi/doi/10.1503/cmaj.109 $-3811)$.

The government's failure to disclose available health data makes it difficult to understand the rationale behind its decisions, or its priorities, critics say (www.cmaj.ca/cgi/doi/10.1503/cmaj.109 -3837). Health Canada treats clinical material on drug safety and efficacy submitted by pharmaceutical companies as confidential business secrets, for example, and refuses to release it without industry blessing.

Instead of adopting the model of the US, in which clinical trial data is more readily accessible, regulatory advisory committee meetings are public and reviewers' comments on clinical data are posted online, Health Canada chose the European approach, in which limited documents are released only after a drug has been approved. But critics say that strategy does not provide the information necessary to make an independent assessment of the safety and efficacy of new drugs.

Even the information that Health Canada is willing to share often requires lengthy access to information request processes to obtain, and is delivered in digitally unusable formats. Health Canada has also rejected the adoption of standards for how long it takes to post adverse drug reaction reports on its website, and has stalled

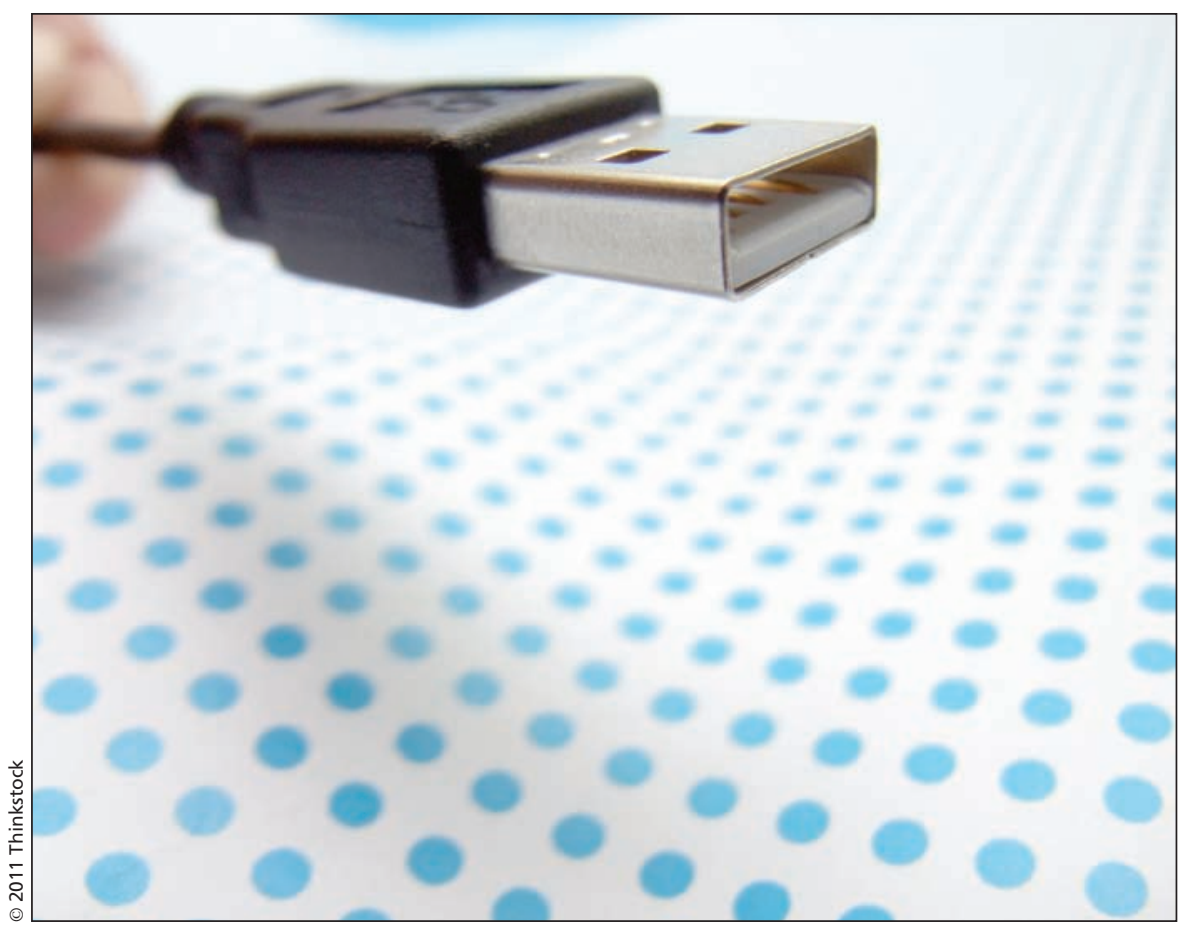

Health datasets were unplugged from the very limited transparency initiative unveiled earlier this year by Prime Minister Stephen Harper's federal government.

action on a public clinical trial registry for five years.

Meanwhile, the US, UK, Australia, Poland, Brazil and India, among other countries, are locked in an "arms races to see who can be more open with their data" (www.cmaj.ca/cgi/doi/10.1503 /cmaj.109-3839).

The US took an early lead when President Barack Obama unveiled an unprecedented Open Government Directive in 2009, obligating federal departments and agencies to take immediate and concrete steps to publicly share the information they maintained internally (www.whitehouse.gov/open/documents /open-government-directive). To date, thousands of collections of "high-value" data have been posted online in userfriendly formats, including comprehensive community health datasets containing a wealth of information on health care quality, cost and access across the country.

Earlier this year, Canada limped into the race with its own Open Government
Initiative, but licensing restrictions and vague requirements around what data is to be shared, and by whom, combined to make the initiative substantially narrower than those underway in other nations (www.cmaj.ca/cgi/doi/10.1503 /cmaj.109-3844). Moreover, the bulk of Canada's health data has yet to be made accessible under the Conservative government's transparency plan.

While the Conservatives declined to answer how they would ensure more transparency of health decisions and datasets, other parties that participated in CMAJ's 2011 election survey called for an expansion of the initiative to include more from, and require more of, all federal departments and agencies.

The Liberals, who released their own comprehensive open government policy in advance of the Conservative initiative, would make open data the "default position" of all departments and agencies (www.liberal.ca/files/pdf /lpcopengov.pdf).

Although the New Democrats were 
more tentative in their support of open government, they did call for further investigation into the transparency measures for health decisions and data adopted by other countries.

The Bloc Québécois, meanwhile, blasted the government's lack of "drive for transparency" in the area of health regulation, particularly consumer safety, and asserted that Canadians have "a right to know and choose what we consume in a free and informed way." Lauren Vogel, CMAJ

Survey question: Several countries, including the United States and United Kingdom have adopted measures to ensure transparency of health decisions and datasets. Will your party compel open regulatory hearings and disclosure of regulatory submissions and the rationale for decisions, as is now the case with the US Food and Drug Administration?

Conservative response:

No response. Rather than participate in CMAJ's 2011 election survey, the Conservatives forwarded a weblink to their party platform. Asked what the rationale was for declining participation, party spokesperson Ryan Sparrow says the weblink constitutes a response to the survey. "That response is the response from the campaign."

\section{Liberal response:}

"A key element of the Liberal plan for democratic renewal is Open Government. Liberals will adopt a new approach to information, issuing government-wide direction that the default position for all departments and agencies will be to release information to the public, both proactively and responsively, after privacy and other legal requirements are met. This initiative will see as many government datasets as possible available to the public online, free of charge in an open and searchable format. Furthermore, all Access to Information requests and responses will be posted online."

\section{New Democrat response:}

"The New Democratic Party of Canada supports open and transparent processes for government decision making particularly when it comes to the health of Canadians. New Democrats would be willing to examine the measures adopted in the United States and the United Kingdom and adopt them if they can provide a benefit to Canadians."

Bloc Québécois response:

"Si Québec est le seul maître d'œuvre quant aux orientations et à la gestion des services de santé et des services sociaux offerts à la population sur son territoire, le gouvernement fédéral a quant à lui la tâche de s'occuper de ses propres champs de responsabilités, des Autochtones à l'évaluation des produits toxiques en passant par l'approbation des nouveaux médicaments. Or, en 2006, la vérificatrice générale du Canada déplorait le fait qu'il était impossible de garantir que Santé Canada s'acquittait bien de ses responsabilités à cet égard.

L'actualisation de la Loi sur les aliments et drogues est nécessaire. En 2008, le gouvernement fédéral a enfin présenté son plan d'action pour assurer la sécurité des produits alimentaires et de consommation. Cependant, le gouvernement conservateur, dans son élan de transparence habituelle, profite de l'occasion pour se dégager de certaines responsabilités qui pourraient avoir des effets néfastes sur la santé de la population, notamment, la privatisation des services d'inspection des aliments.

Que ce soit pour les aliments ou les produits de santé, le Bloc Québécois reconnaît l'importance d'une réglementation qui permette à la fois de protéger la santé des consommateurs, de respecter l'accès des consommateurs aux produits et de garantir l'innocuité et la qualité des produits. En ce qui a trait à la protection du consommateur, la position du Bloc Québécois reste toujours la même : nous avons le droit de savoir et de choisir ce que nous consommons de façon libre et éclairée.

C'est pourquoi le Bloc Québécois continuera de veiller à ce que le gouvernement fédéral prenne ses responsabilités, particulièrement en ce qui a trait à la réglementation et à l'étiquetage des aliments pouvant présenter certains risques pour la santé des Québécois(e)s, et ce, en toute transparence et dans le respect des champs de compétences du Québec en matière de santé."

CMAJ 2011. DOI:10.1503/cmaj.109-3879

Editor's note: Seventh of a series of stories on CMAJ's 2011 election survey:

Part 1: Health transfers (www.cmaj.ca/cgi/doi/10.1503/cmaj.109-3865)

Part 2: Pharmacare (www.cmaj.ca/cgi/doi/10.1503/cmaj.109-3870)

Part 3: Health human resources (www.cmaj.ca/cgi/doi/10.1503/cmaj.109-3875)

Part 4: Home/palliative care (www.cmaj.ca/cgi/doi/10.1503/cmaj.109-3876)

Part 5: Research (www.cmaj.ca/cgi/doi/10.1503/cmaj.109-3877)

Part 6: Food safety (www.cmaj.ca/cgi/doi/10.1503/cmaj.109-3878)

Translation by Lauren Vogel, CMAJ 